\title{
Exploration of Phyllosphere Bacteria From Andaliman (Zanthoxylum acanthopodium DC.)
}

\author{
Debie Rizqoh ${ }^{1,2,{ }^{*}}$ Sipriyadi $^{2,3}$ Shella Sharon ${ }^{4}$ Indah Dwi Rachmawati ${ }^{4}$ Wulan \\ Okta Kumala ${ }^{4}$ Cintya Nabilla Putri ${ }^{4}$
}

\author{
${ }^{I}$ Departement of Microbiology dan Immunology, Faculty of Medicine, University of Bengkulu, Bengkulu, \\ Indonesia \\ ${ }^{2}$ Division of Communicable Disease, Center for Tropical and Coastal Medicine Research, University of \\ Bengkulu, Bengkulu, Indonesia \\ ${ }^{3}$ Departement of Microbiology, Faculty of Matematics and Sciences, University of Bengkulu, Bengkulu, \\ Indonesia \\ ${ }^{4}$ Bachelor Student of Medical Science, Faculty of Medicine, University of Bengkulu, Indonesia \\ *Corresponding author. Email: debierizqoh@unib.ac.id
}

\begin{abstract}
Phyllosphere bacteria were bacteria that inhabit around the leaf surface. Several studies showed the potential of phyllosphere bacteria in producing bioactive compounds, one of which is antimicrobial compounds. Andaliman (Zanthoxylum acanthopodium DC.) was a plant from the Rutaceae family that was commonly found in North Sumatra, and its fruit was widely used as a spice in traditional cooking by the Batak tribe. Several studies showed that the andaliman terpenoid has antioxidant and antimicrobial activity and an immunostimulating effect. This study aimed to explore the potential of andaliman phyllosphere bacteria. The research design method was a qualitative experimental model. The research stages used in compiling this paper consisted of phyllosphere bacteria isolation, phyllosphere bacteria morphological characterization, and Gram stain. This study succeeded in isolating 206 colonies of andaliman phyllosphere bacteria with various colony forms and cell morphology. From 64 samples of phyllosphere bacterial isolate observed, we found 25 different colony forms, and all samples were Gram-positive bacteria. Microscopic observations of gram staining showed that 44 isolates (68.75\%) were cocci, 17 isolates $(26.56 \%)$ were in the form of bacillus, and three isolates $(4.68 \%)$ were in the form of coccobacillus.
\end{abstract}

Keywords: phyllosphere, bacteria, andaliman, variation

\section{INTRODUCTION}

Phyllosphere bacteria are the most surface leaf inhabitant microbes [1]. In high humidity, such as in tropical and temperate regions, various leaf microflora is found there. Some studies reported that phyllosphere bacteria have antimicrobial compounds that can inhibit some pathogen microbes, such as Escherichia coli, Staphylococcous aureus, Candida tropicalis, and Candida albicans [2]. Some phyllosphere bacteria can produce a bioactive compound to compete with other microorganisms for space and nutrients to grow [1].

Andaliman (Zanthoxylum acanthopodium DC.) is a unique herbal plant that grows a lot in North
Sumatra, Indonesia. This plant is widely available in the Toba Samosir and North Tapanuli regencies, North Sumatra, at an altitude of $1,500 \mathrm{~m}$ above sea level, found growing wild in the Tapanuli area and used as a spice in traditional Batak dishes.

Some study proves that Andaliman extract has a potential source of antimicrobial and antioxidant compounds [3-4]. Andaliman extract can inhibit the growth of Bacillus stearothermophilus, Pseudomonas aeruginosa, Vibrio cholera, Salmonella thypimurium, and Aspergillus sp [3,5].

The objective of this study was to explore the potential of Andaliman Phyllosphere bacteria to produce antimicrobial compounds. 


\section{MATERIALS AND METHODS}

\subsection{Research design}

The research method was carried out in a qualitative experimental approach in the laboratory. The research stages consisted of the isolation of phyllosphere microbes and characterization of the morphological bacteria of the phyllosphere.

\subsection{Sample collection}

Andaliman plant samples were taken in Parsoburan, Toba Samosir Regency, North Sumatra.

\subsection{Isolation of phyllosphere bacteria}

The media used in the isolation of phyllosphere bacteria were Kings'B Media. Each andaliman plant leaves three samples taken. Phyllosphere bacteria are obtained by inserting andaliman leaves into a tube containing a physical saline solution until submerged. The solution is then pulverized for five minutes. The leaves are removed from the tube containing the physiological salt with sterile tweezers. The solution was diluted by a tube dilution method with a dilution of $10^{-1}$ to $10^{-4}$. Samples in each dilution tube were implanted onto King's B media by the scatter plate technique. All cultures were incubated for 24 hours at room temperature. Single colonies that appear to be different are selected to be purified on the King's B medium.

\subsection{Characterization of the morphological bacteria}

The phyllosphere bacteria characteristics were assessed according to Leboffe and Pierce [6]. Pure phyllosphere bacterial isolates were identified morphologically based on colony color, margin, elevation, texture, and shape. It may have a round, irregular and punctual shape. Then, the margin could be entire, undulate, lobate, filamentous, or rhizoid. Elevation may be flat, high, convex, pulvinate, or umbonate. The texture could be moist, mucoid, or dry. And the pigment or colour of the colony may be opaque, translucent, glossy and matte.

Then, Gram staining was performed to determine the Gram-positive or Gram-negative bacterial groups and the shape of the bacterial cells. The colony shape could be coccus, bacillus, spiral, or coccobacillus.

\section{RESULT AND DISCUSSION}

Phyllosphere bacteria in this study were isolated from the leaves of Andaliman plants. The isolation of phyllosphere bacteria was carried out using a multilevel dilution method from $10^{-1}$ to $10^{-4} ; 0.1 \mathrm{ml}$ of the suspension from each dilution was taken and spread in King's B media. Media containing the sample were incubated at room temperature in obscurity and observed every 24 hours until colony growth occurred (Figure 1). The number of phyllosphere bacteria colonies obtained in this study reached 206 colonies.

Phyllosphere bacteria are bacteria that generally live on the surface of plant leaves. Phyllosphere bacteria are found in the stomata, along with the leaf bones and epidermal cell walls. Phyllosphere bacteria can live on the leaves because of organic compounds such as fructose, sucrose, organic acids, amino acids, and vitamins used as a source of carbon, energy, and compounds that trigger plant growth [7]. The phyllosphere has a very diverse bacterial population. Bacterial populations of phyllosphere between one or the other plant species are very different, primarily due to fluctuations in the physical environment and nutritional conditions at the leaf surface [1]. Plant pathogenic bacteria can be inhibited through the antagonistic mechanism of the phyllosphere bacteria to inhibit the occurrence of disease in plants [8].

Phyllosphere bacteria in this study were isolated from the leaves of Andaliman plants ( $Z$. acanthopodium DC.), which were sent from Parsoburan District, Toba Samosir Regency, North Sumatra, Indonesia. Isolation of phyllosphere bacteria was carried out by dilution method and grown in King's B. Media King's B is a non-selective bacterial growth medium that contains glycerol as an abundant carbon source. King's B media is often used for the isolation of diverse bacterial colonies from the phyllosphere.

Morphology of several colonies of andaliman phyllosphere bacteria was observed, among others, from the colony shape, margin, elevation, texture, and color. There were 64 phyllosphere bacterial colonies observed. Colony forms are generally circular (circular) and irregular (irregular), margins or edges are smooth, wavy, and irregular, flat elevation, mostly wet in texture, colors vary from white to yellow (Figure 2). 

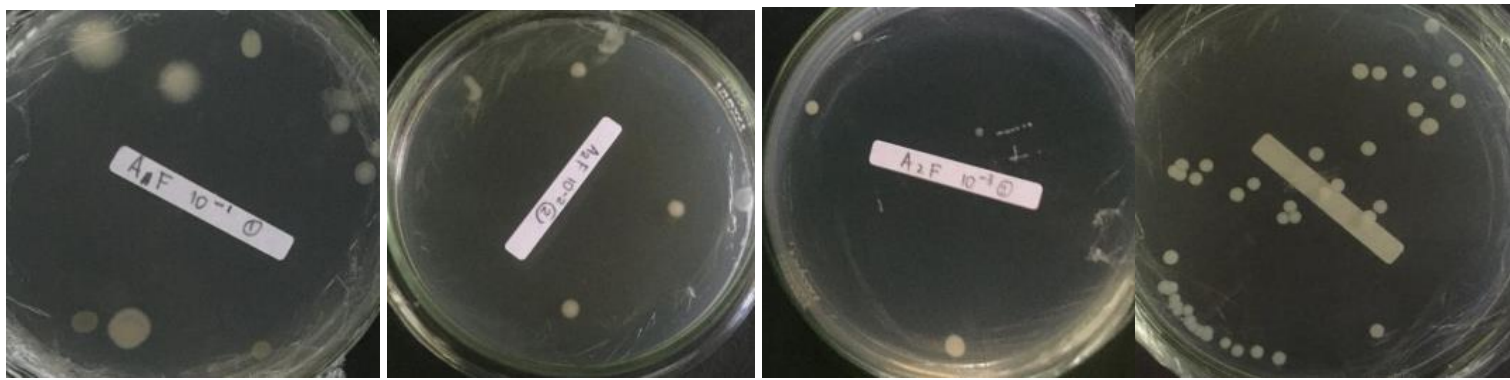

Figure 1. The growth of some Andaliman phyllosphere bacteria colonies in King's B medium from different dilutions after $24 \mathrm{~h}$ incubation in $37^{\circ} \mathrm{C}$.
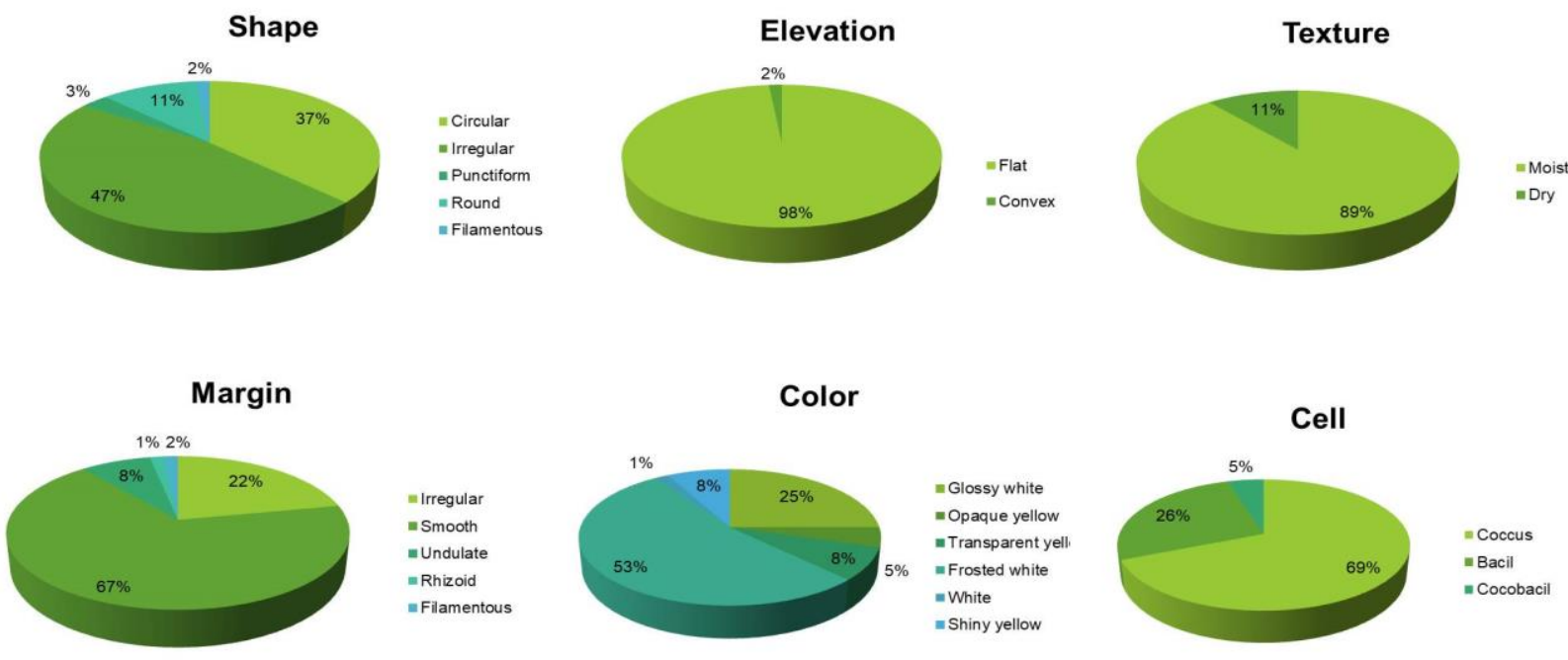

Figure 2. Characteristic Variations of Andaliman Phyllosphere Bacteria Colonies and Cells.

Based on observation of bacterial colonies, there were 25 different characteristics. The dominant characteristics were irregular in shape and margin. Other dominant colony characteristics were flat elevation, moist texture, and white color.

The results of Gram staining on these isolates showed that all the phyllosphere bacterial isolates that were successfully cultured were Gram-positive bacteria (Table 1). Phyllosphere bacteria have Gram-positive bacterial physiology potential and communities higher than Gramnegative bacteria [9]. Microscopic observations of gram staining showed that 44 isolates $(68.75 \%)$ were cocci, 17 isolates $(26.56 \%)$ were in the form of bacillus, and three isolates $(4.68 \%)$ were in the form of coccobacillus.

This study found that there were colony variations, such as shape, color, and edges. The colony structure of phyllosphere bacteria is influenced by environmental parameters such as ultraviolet radiation, air pollution, humidity, nutrition, and temperature. Colony variations can also occur due to factors such as the type of culture media, temperature, and incubation time. Based on the research of Leboffe and Piece (2012), macroscopic observations of the characterization of phyllosphere bacterial colonies were carried out by observing the shape, edge shape, elevation, texture, and pigment of the colony. The colony characterization observations obtained were still less specific because the parameters used were still limited, so that the results of observations on the characterization of several isolates had similarities [6].

Fluctuating ultraviolet radiation is one of the predominant conditions in the foliar environment that causes the bacterial phyllosphere to adapt. The striking feature of phyllosphere bacteria is the pigmentation which protects against ultraviolet radiation. The population of phyllosphere bacteria is more pigmented than bacteria from the soil [10]. Besides, the presence of extracellular polysaccharides (EPS) protects plantbacteria against dessiccation and osmotic stress [11]. EPS can protect bacteria from water limitations, help cells adjust to the surface of leaves and protect them from the activity of antibiotics or antimicrobial compounds of other bacteria [7]. The effect of antimicrobial compounds produced by several phyllosphere bacteria can also affect the diversity of phyllosphere bacteria [1]. 
Plant surfaces also experience rapid temperature changes, as does the humidity in response to dew and rain. The presence of aliphatic compounds in the cuticular layer determines the physicochemical properties of the leaf surface and ensures permeability and humidity, making it easier to bind microorganisms [12]. Water permeability can be critical to the survival and growth of the bacterial phyllosphere. In general, bacteria maintain cuticle permeability with biosurfactant secretion [11].

The phyllosphere microbiome contains a great variety of bacteria, fungi, actinomycetes, cyanobacteria and viruses [11]. As part of the microbiome in the plant, phyllosphere microbes can act as mutualists promoting the growth of the plant and environmental stressor tolerance, commensals using the leaf as their habitat for growth, or as antagonistic pathogens [10]. Microorganisms usually assist the host plant and functional communication with the surrounding environment by establishing epiphytic or endophyte life cycles in the phyllospheric environment. [11].

The study of bacterial colonizers of leaves has been mainly restricted to aerobic culturable bacteria. Pseudomonas syringae and Erwinia (Pantoea) spp. are the most ubiquitous bacterial participants of phyllosphere communities [1]. Another study report that the phylogenetic tree phyllosphere bacteria showed a genetic relationship with the genus of Klebsiella, Pseudomonas, and Bacillus [2].

Tabel 1. Gram Staining observation of Andaliman Phyllosphere Bacteria

\begin{tabular}{lll}
\hline $\begin{array}{l}\text { Cell } \\
\text { Shape }\end{array}$ & Andaliman Phylospher Bacteria Code & $\begin{array}{l}\text { Bacterial } \\
\text { Gram }\end{array}$ \\
\hline Coccus & AF1, AF2, AF3, AF5, AF6, AF11, & Positive \\
& AF12, AF13, AF14, AF15, AF16, AF17, & \\
& AF18, AF20, AF21, AF26, AF27, AF28, & \\
& AF29, AF30, AF31, AF32, AF34, AF35, & \\
& AF36, AF37, AF38, AF39, AF40, AF41, & \\
& AF42, AF43, AF45, AF46, AF50, AF51, & \\
& AF54, AF55, AF56, AF58, AF61, AF62, & \\
& AF63, AF64 & \\
Basil & AF4, AF7, AF8, AF10, AF19, AF22, & \\
& AF23, AF24, AF25, AF33, AF47, AF48, & \\
& AF49, AF52, AF57, AF59, AF60 & \\
Cocobasil & AF9, AF44, AF53 \\
& &
\end{tabular}

\section{CONCLUSION}

This study did isolation of culturable andaliman phyllosphere bacteria which have colonies and cells morphological diversity. This study was still having limited information about andaliman phyllosphere bacteria. The study needs biochemical and genetic identification to know the species of phyllosphere bacteria.

\section{ACKNOWLEDGMENT}

This research is supported by the grant from PNBP Faculty of Medicine, University of Bengkulu 2019. Thank you for the support.

\section{REFERENCES}

[1] S.E. Lindow, M.T. Brandl, Microbiology of the phyllosphere, Applied Environmental Microbiology 69(4) (2003) 1875-1883. DOI: https://doi.org/10.1128/AEM.69.4.1875-1883.2003

[2] D. Rizqoh, N.R. Sari, R.N. Wati, F. Santosa, R. Hasanah, Aktivitas bakteri filosfer daun reundeu (Staurogyne longata) sebagai penghasil senyawa antimikroba potensial, Jurnal Analis Laboratorium Medik 1(1) (2016) 1-7. [In Bahasa Indonesia]

[3] Y.K. Asbur, Pemanfatan andaliman (Zanthoxylum acanthopodium DC) sebagai tanaman penghasil minyak atsiri, Jurnal Kultivasi 17(1) (2018) 537 543. DOI

https://doi.org/10.24198/kultivasi.v17i1.15668 [In Bahasa Indonesia]

[4] H. Shasti, T.A. Siregar, Uji Aktivitas Antibiotik Ekstrak Buah Andaliman (Zanthoxylum acanthopodium DC) Terhadap Pertumbuhan Bakteri Staphylococcus aureus Secara In Vitro, Jurnal Ibnu Sina Biomedika 2(1) (2017) 229-35. DOI: https://doi.org/10.3975/cagsb.2017.02.15 [In Bahasa Indonesia]

[5] Maysarah, Isolasi dan uji kemampuan antifungal fungi endofit dari tanaman andaliman (Zanthoxylum acanthopodium DC.) terhadap fungi perusak makanan, Thesis, Universitas Sumatera Utara, 2009. [In Bahasa Indonesia]

[6] M.J. Leboffe, B.E. Pierce, Brief Microbiology Laboratory Theory \& Application 2nd Edition, Englewood, Morton Publishing, 2012.

[7] N. Rina, N.P.R.A. Krishanti, A. Akhdiya, A.T. Wahyudi, Penapisan bakteri filosfer penghasil senyawa bioaktif Xanthomonas oryzae pv. oryzae penyebab penyakit hawar daun bakteri pada padi, Jurnal Sumberdaya Hayati 2(1) (2016) 19-24. DOI: https://doi.org/10.29244/jsdh.2.1.19-24

[8] J.M. Whipps JM, P. Hand, D. Pink, G.D. Bending, Phyllosphere microbiology with special reference to diversity and plant genotype. Journal of Applied Microbiology 105 (2008) 1744-55. DOI: https://doi.org/10.1111/j.1365-2672.2008.03906.x 
[9] B. Zhang, Z. Bai, D. Hoefel, X. Wang, L. Zhang, Z. Li, Microbial diversity within the phyllosphere of different vegetable species, Current Research, Technology and Eucation Topics in Applied Microbiology and Microbial Biotechnology, Formatex, 2010, pp.1067-1077.

[10] B.W.G. Stone, E.A. Weingarten, C.R. Jackson. The role of the phyllosphere microbiome in plant health and function, Annual Plant Reviews online 1(2) (2018) 533-556. DOI: https://doi.org/10.1002/9781119312994.apr0614.

[11] N. Sivakumar, R. Sathishkumar, G. Selvakumar, R. Shyamkumar, K. Arjunekumar, Phyllospheric Microbiomes: Diversity, Ecological Significance, and Biotechnological Applications, Plant Microbiomes for Sustainable Agriculture, Sustainable Development and Biodiversity 25(5) (2020) 113-172. DOI: https://doi.org/10.1007/9783-030-38453-1 5

[12] C. Sadler, B. Schroll, V. Zeisler, F. Waßmann, R. Franke, L. Schreiber, Wax and Cutin Mutants of Arabidopsis Quantitative Characterization of The Cuticular Transport Barrier in Relation to Chemical Composition, Journal Biochimica et Biophysica Acta 1861(9 Pt. B) (2016) 1336-1344. DOI: https://doi.org/10.1016/j.bbalip.2016.03.002 